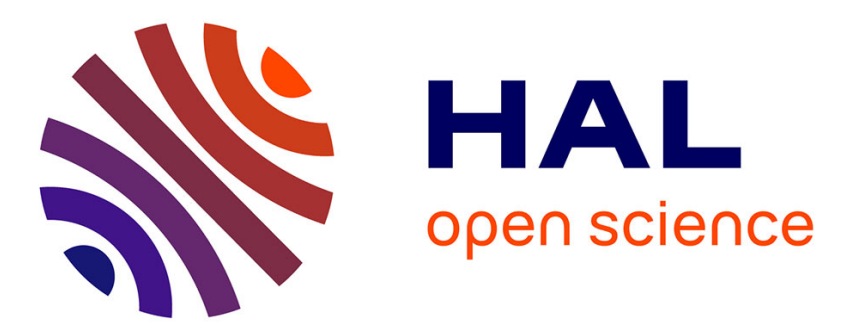

\title{
Insight into plasma degradation of paracetamol in water using a reactive molecular dynamics approach
}

Pascal Brault, Mado Abraham, Aïda Bensebaa, Olivier Aubry, Dunpin Hong, Hervé Rabat, Monica Magureanu

\section{- To cite this version:}

Pascal Brault, Mado Abraham, Aïda Bensebaa, Olivier Aubry, Dunpin Hong, et al.. Insight into plasma degradation of paracetamol in water using a reactive molecular dynamics approach. Journal of Applied Physics, 2021, 129 (18), pp.183304. 10.1063/5.0043944 . hal-03222779

HAL Id: hal-03222779

https://hal.science/hal-03222779

Submitted on 10 May 2021

HAL is a multi-disciplinary open access archive for the deposit and dissemination of scientific research documents, whether they are published or not. The documents may come from teaching and research institutions in France or abroad, or from public or private research centers.
L'archive ouverte pluridisciplinaire HAL, est destinée au dépôt et à la diffusion de documents scientifiques de niveau recherche, publiés ou non, émanant des établissements d'enseignement et de recherche français ou étrangers, des laboratoires publics ou privés. 


\title{
Insight into plasma degradation of paracetamol in water using a reactive molecular dynamics approach
}

Pascal Brault ${ }^{1, *}$, Mado Abraham ${ }^{1}$, Aïda Bensebaa ${ }^{1}$, Olivier Aubry ${ }^{1}$, Dunpin Hong ${ }^{1}$, Hervé Rabat $^{1}$, Monica Magureanu ${ }^{2}$

${ }^{1}$ GREMI CNRS Université d'Orléans BP6744, 14 rue d'Issoudun, 45067 Orléans Cedex 2, France

${ }^{2}$ Department for Plasma Physics and Nuclear Fusion, National Institute for Lasers, Plasma and Radiation Physics, Atomistilor Street 409, Magurele, Ilfov 077125, Romania

* pascal.brault@univ-orleans.fr

\begin{abstract}
Plasma-produced reactive oxygen and nitrogen species (RONS) are expected to promote micropollutant degradation in water and more generally in liquids. Among these species, the hydroxyl radical (HO') is recognized as being the most efficient. Molecular dynamics simulations were carried out to determine the reaction steps of $\mathrm{HO}^{\bullet}$ interaction with the paracetamol molecule in water, a pharmaceutical residue that is frequently detected in surface and tap water and is well documented. Calculations were performed at various temperatures to determine the oxidation pathways, the intermediate and final products were identified. Assuming a ratio of $10 \% \mathrm{HO}^{\circ}$ in water, it was found that a local temperature of $2500 \mathrm{~K}$ is required to decompose paracetamol to $\mathrm{CO}, \mathrm{H}_{2} \mathrm{O}, \mathrm{NH}_{3}$, and $\mathrm{C}_{2} \mathrm{H}_{2}$.
\end{abstract}

Keywords: Molecular dynamics simulations; plasma processing; plasma treatment; reactive oxygen species; wastewater; advanced oxidation; ReaxFF 


\section{Introduction}

The presence of pharmaceutical residues, such as paracetamol $\left(\mathrm{C}_{8} \mathrm{H}_{9} \mathrm{NO}_{2}\right)$, in water is becoming a major concern worldwide due to the risk that they represent for the environment and for health [1]. Moreover, paracetamol is suspected to have endocrine disruptive effects on both males and females as it is a prostaglandin synthesis inhibitor [2-4]. Electric-discharge non-thermal plasmas have been proposed as an efficient advanced oxidation technique for the abatement of organic micropollutants, including pharmaceutical residues [5-9], as nonthermal plasmas in and in contact with liquids, are rich sources of reactive oxygen and nitrogen species (RONS) such as $\mathrm{HO}^{\circ}, \mathrm{O}_{2}{ }^{--}, \mathrm{HOO}^{\circ}, \mathrm{O}_{3},{ }^{1} \mathrm{O}_{2}, \mathrm{O},{ }^{\circ} \mathrm{NO}, \mathrm{H}_{2} \mathrm{O}_{2}, \mathrm{ONOO}^{-}, \mathrm{NO}_{2}^{-}$ and UV radiation [10-23]. One of the major goals of studying plasma-liquid interactions and in particular, the interactions of RONS with organic molecules, is to understand the basic mechanisms and predict the products generated [12]. Since degradation mechanisms are mainly radical based, atomistic simulations such as reactive molecular dynamics simulations (MD) are expected to be of great help [24]. Interactions between gas-phase plasma and liquid have already been addressed, albeit rarely, using MD in order to study the effects of RONS, especially atomic oxygen, on water itself [25-28]. To our knowledge, however, no MD studies on the interaction of RONS with pharmaceutical residues have been conducted, contrary to studies on biological molecules [29-30].

In the present study, MD simulations were carried out with a temperature ramping between $300 \mathrm{~K}$ and $2500 \mathrm{~K}$ to determine the temperature domains for successive $\mathrm{C}-\mathrm{C}$ and $\mathrm{C}-\mathrm{N}$ bond breaking by observing the detailed action of $\mathrm{HO}^{\circ}$ on the paracetamol molecule. MD simulations were also carried out at constant temperatures of 300, 1600 and $2500 \mathrm{~K}$ respectively in order to confirm the results obtained with the ramping temperature simulations. These simulations are not strictly plasma simulations in that no electrons, ions or UV light are present. They are intended to predict what happens when including active 
radicals in polluted water. Varying the temperature is a way of "simulating" local energetic changes that lead to overcoming dissociation barriers. This will further provide information about the order in which the bonds successively break.

\section{Molecular dynamics simulations}

Molecular dynamics simulations calculate the trajectories of an ensemble of $N$ species. They consist in solving the Newtonian equations of motion

$$
m_{i} \frac{d^{2}}{d t^{2}} \vec{r}_{i}(t)=-\vec{\nabla}_{r_{i}} V\left(\vec{r}_{1}(t), \cdots, \vec{r}_{N}(t)\right)=\vec{F}_{i}(t), \quad i=1, \cdots, N
$$

where $\vec{r}_{i}(t)$ is the position of species $i$ at time $t, V$ is the total interaction potential function and $\vec{F}_{i}(t)$ is the force field acting on species $i$ at time $t$. Solving such a set of equations requires knowledge of the initial conditions, which can be selected so as to match experimental conditions and the interaction potential $V$ or the force field $\vec{F}$.

The molecular dynamics simulations were carried out using the reactive force field ReaxFF [31] to describe the interaction between the $\mathrm{C}, \mathrm{H}, \mathrm{N}, \mathrm{O}$ atoms. Basically, this force field is bond-order dependent, which allows an accurate description of bond breaking and formation. Bond-orders were calculated from interatomic distances at each MD step to determine connectivity. Thus, bonds can break and form throughout the simulation. Non-bonded interactions were evaluated between each pair of atoms, independently from the connectivity. Too close non-bonded atoms were avoided by a shielding term. Moreover, polarization effects were accounted for by using a geometry dependent charge calculation model $[32,33]$. ReaxFF force field belongs to the family of variable charge reactive force fields [34]. It has been validated by numerous experimental results and a large set of literature theoretical data issued from geometry optimizations and bond dissociation quantum data, over the last 20 years, which leads to its robustness [32-34]. MD simulations have been used to examine the behavior of plasma-generated species $\left(\mathrm{OH}\right.$ radicals, $\mathrm{O}$ atoms, $\left.\mathrm{HO}_{2}, \mathrm{H}_{2} \mathrm{O}_{2}\right)$ in water $[25,27,28]$, 
valuable for understanding plasma-liquid interaction. In the context of biomedical applications of plasma, ReaxFF forcefields have been successfully applied to describe bond formation/breaking at the interaction of reactive oxygen species with various biomolecules, such as lipids, proteins, DNA etc., as well as with components of the bacterial cell wall [2931, 35-40]. All these are organic molecules containing similar bonds as in the present study. Although the exact mechanisms are difficult to determine experimentally, so a direct comparison with experiments is often not straightforward, predictions of these simulations appear to be realistic, and at least qualitatively, in agreement, with experimental observations [29-31,38-40]. ReaxFF studies have also been found to accurately describe various bond dissociation and formation for hydrocarbons and fullerenes [32,41], as well as high temperature oxidation of hydrocarbon, successfully predicting oxidation products and reproducing reaction rates with $\mathrm{O}_{2}$ of several small aliphatic and aromatic compounds [42]. Qualitative agreement with experimental observations has also been obtained for ReaxFFbased MD simulations of oxidative and thermal treatment of polymeric materials (containing $\mathrm{C}, \mathrm{H}, \mathrm{O}$ and $\mathrm{N}$ ) to yield carbon nanofibers [43-45]. The combustion kinetics of various fuels and fuel mixtures at high temperatures and pressures has also been investigated by ReaxFF calculations $[46,47]$ and the studies demonstrate the ability of this method to capture complex combustion dynamics and the trend of reactivity for different hydrocarbons confirmed by experimental measurements.

For this study, a $15.3 \times 15.3 \times 15.3 \AA^{3}$ simulation box was designed with randomly placed 10 $\mathrm{HO}^{\bullet}, 100 \mathrm{H}_{2} \mathrm{O}$ and one paracetamol molecules, separated by a distance greater than $2.5 \AA$ [48]. This gives a water density close to $1.0 \mathrm{~g} . \mathrm{cm}^{-3}$. These ratios were chosen in light of the typical values recorded in the literature $[12,15,26,49]$ : the typical concentration level of $\mathrm{HO}^{*}$ in water is $10^{15}-10^{17} \mathrm{~cm}^{-3}$ [50-53]. Literature studies on paracetamol degradation most often 
investigate solutions with concentrations of tens of $\mathrm{mg} \cdot \mathrm{L}^{-1}$. Considering, for instance, a paracetamol concentration of $15 \mathrm{mg} \cdot \mathrm{L}^{-1}$, this means $6 \times 10^{16}$ molecules.cm ${ }^{-3}$.

$\mathrm{HO}^{\bullet}$ densities of $10^{18}$ molecules. $\mathrm{cm}^{-3}$ have been reported for plasmas generated in water [12, 40]. Measurements of $\mathrm{HO}^{\bullet}$ densities in plasmas generated in gas phase in contact with water have detected values in the range of $10^{15}-10^{17}$ molecules. $\mathrm{cm}^{-3}$, depending on the type of discharge, operating parameters, gaseous atmosphere and measurement method [40-42]. For discharges in air above liquid, $\mathrm{HO}^{\bullet}$ densities of $10^{17} \mathrm{~cm}^{-3}$ are reported [51]. Similar values (3.5-10.9 ppm, i.e. 1.2-3.8 $\times 10^{17} \mathrm{~cm}^{-3}$ ) are also found in DBD generated in Ar with an admixture of water vapor [53]. Moreover, as active species are continuously delivered while the organic pollutant is being degraded, the relative concentration of active species can increase. Therefore, the ratio of 10:1 between $\mathrm{HO}^{\circ}$ and paracetamol selected here is a reasonable assumption. Tap or surface water real paracetamol concentrations are in the range of $1 \mathrm{ng} . \mathrm{L}^{-1}$ to a few tens of $\mu \mathrm{g} . \mathrm{L}^{-1}$. To apply wastewater treatment, however, the samples that are accumulated are too diluted and need to be re-concentrated for a treatable amount to be obtained. On the other hand, pollutants can be treated at the source where they are more abundant. In addition, when considering even the highest paracetamol concentration of mg.L${ }^{1}$, the density ratio with water is below $10^{-6}$. In this case, it is almost impossible for the degradation products of paracetamol to interreact. Studying the degradation process with only one paracetamol molecule is therefore justified. On the contrary, it would mean that an external "force" is acting to locally increase the paracetamol content. Such forces can come from the plasma-induced convection or forced flow [12], which can constantly supply paracetamol. This is also consistent with the fact that the plasma-liquid affected zone is limited to the first ten to $100 \mu \mathrm{m}$ at the liquid surface [12]. Treating the pollutants efficiently thus requires that they should be constantly brought to this zone. 


\section{$3 \quad$ Results and discussion}

A first set of simulations was carried out to study the temperature thresholds of the decomposition sequence of paracetamol in water. To complete this first attempt, an initial equilibration step at $300 \mathrm{~K}$ was conducted during $5 \times 10^{6}$ timesteps without handling reactions. Then simulations were performed applying a temperature ramp between 300 and $2500 \mathrm{~K}$ during $40 \times 10^{6}$ timesteps and allowing all possible reactions to occur. The last equilibration step lasted for $5 \times 10^{6}$ timesteps at $2500 \mathrm{~K}$. The timesteps were fixed at $0.1 \mathrm{fs}$, so the total simulation time was $5 \mathrm{~ns}$. This short integration time is required for a good description of fast hydrogen atom motion.

Three other sets of simulations were carried out at constant temperatures of $300 \mathrm{~K}, 1600 \mathrm{~K}$ and $2500 \mathrm{~K}$ in order to check whether ramping temperature simulations induced biases in the intermediate and final products [42], especially for the highest temperature where the final products should be the same. The procedure followed the same design as for the temperature ramp: a first equilibration step at the desired temperature during $5 \times 10^{6}$ timesteps without allowing reactions, followed by a simulation with $45 \times 10^{6}$ timesteps with reactions allowed. All the calculations have been carried out using LAMMPS [54, 55] and ADF [56, 57] softwares with the ReaxFF force field parametrized by Rahaman et al. [31]. 

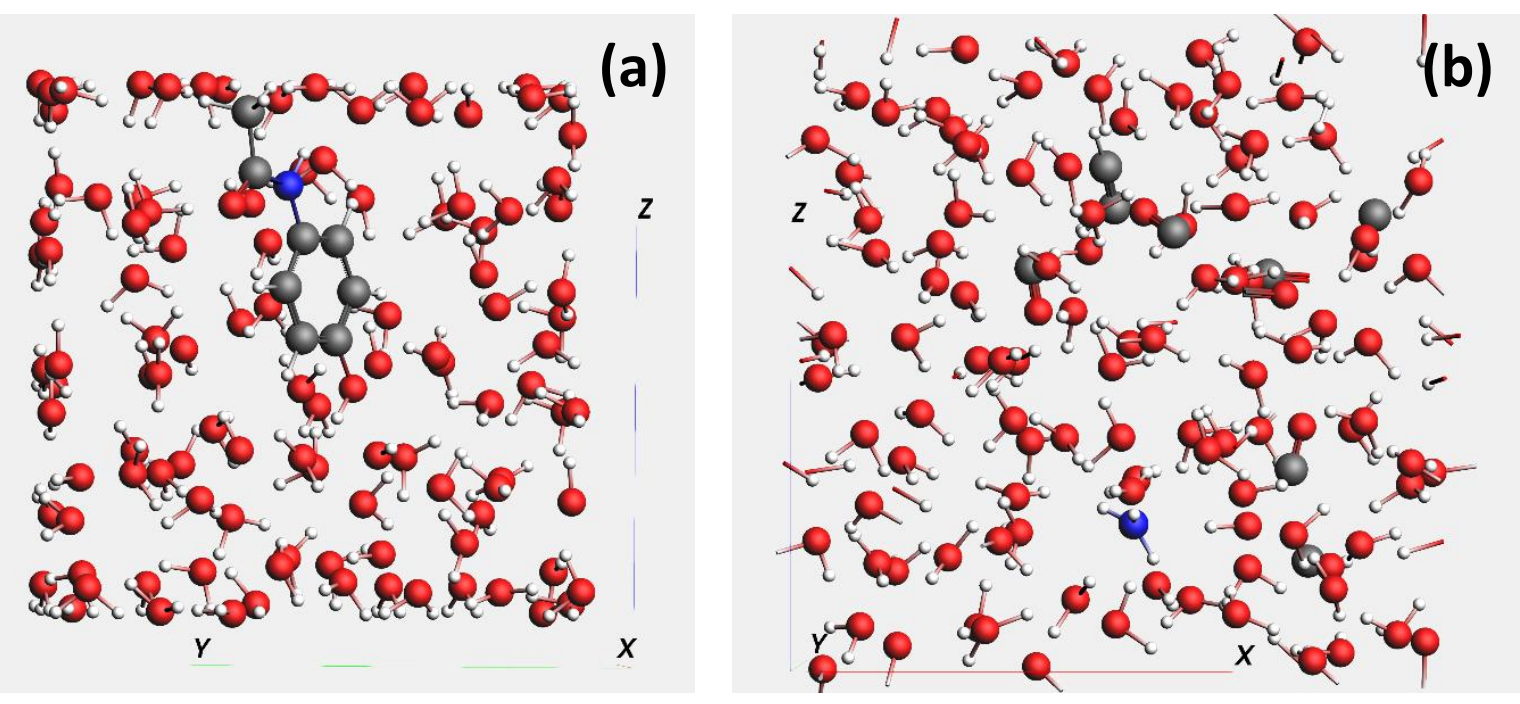

Figure 1: Snapshots of (a) initial and (b) final, $t=5 \mathrm{~ns}$, configuration. Red, white, grey and blue balls are oxygen, hydrogen, carbon and nitrogen atoms respectively. Color online only.

Figure 1 provides snapshots of the initial and final configuration of $\mathrm{HO}^{*}$ interaction with paracetamol. The final degradation products after ramping the temperature up to $2500 \mathrm{~K}$ were $6 \mathrm{CO}, 1 \mathrm{C}_{2} \mathrm{H}_{2}$ and $1 \mathrm{NH}_{3}$. Other species were $103 \mathrm{H}_{2} \mathrm{O}, 1 \mathrm{H}_{3} \mathrm{O}$ and $1 \mathrm{H}_{2}$. $\mathrm{HO}^{\circ}$ radicals were no longer present. Figure 2 displays the time, and thus the temperature, of the formation of the degradation products. 


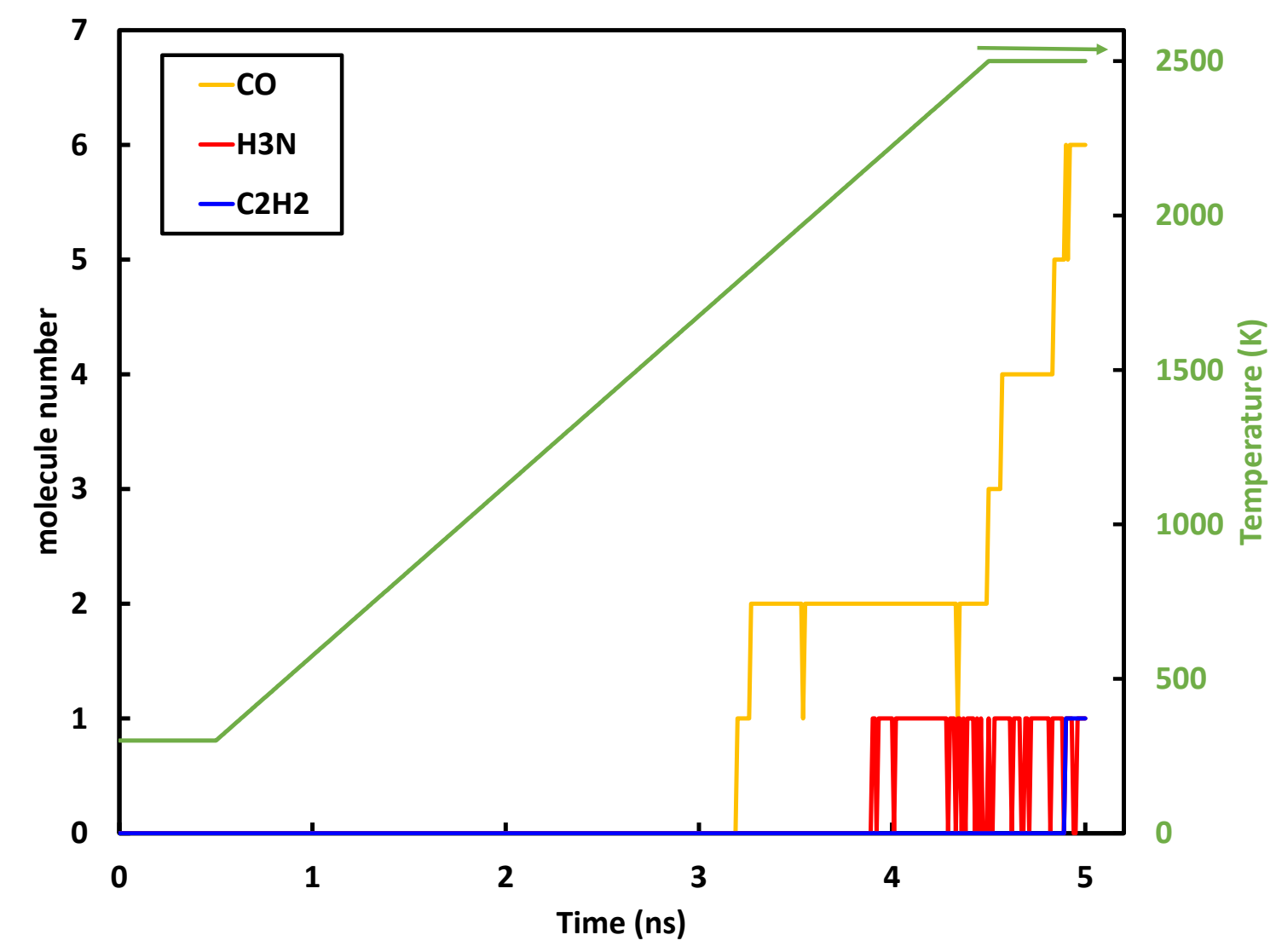

Figure 2: Time evolution of final paracetamol degradation products $\left(\mathrm{CO}, \mathrm{C}_{2} \mathrm{H}_{2}\right.$ and $\left.\mathrm{NH}_{3}\right)$.

Paracetamol degradation starts very quickly and evolves slowly up to $1825 \mathrm{~K}$, with progressive deformation of the hexagonal carbon ring. The $\mathrm{HO}^{\bullet}$ radicals attack $\mathrm{C}$ atoms to form a $\mathrm{CO}$ bond that leads to $\mathrm{C}-\mathrm{C}$ bond breaking $(\mathrm{t}<3.3 \mathrm{~ns}$ ) on the non-ring side of paracetamol. At the same time, the $6 \mathrm{C}$ ring is transformed into a linear chain between 2 and $3.4 \mathrm{~ns}$ terminated by $\mathrm{O}$ on one side and $\mathrm{NH}$ on the other. The $\mathrm{NH}$ termination is dissociated, forming $\mathrm{NH}_{3}$ by interaction with warm $\mathrm{H}_{2} \mathrm{O}(2170 \mathrm{~K})$ leading to a C-O termination in the form of a linear HO-C-C-C-C-C-C-O product. Between 4.5 and 5.0 ns (plateau at 2500K), this product is dissociated, each $\mathrm{C}$ atom one after the other, leading to 4 new $\mathrm{CO}$ radicals. And finally, a $\mathrm{C}_{2} \mathrm{H}_{2}$ molecule remains. Additional simulations showed that $\mathrm{C}_{2} \mathrm{H}_{2}$ is further dissociated to $2 \mathrm{CO}$ radicals above $3000 \mathrm{~K}$. 
The fragments do not display perfect valency. This is due to the high temperature that does not allow stabilization of the intermediate compounds. This persists at the end of the simulation since there is no further relaxation step, which would be required for direct comparison with experimental ex-situ analysis. Moreover, the bond order differs from the initial one, especially for linear radicals: this comes from the way in which ReaxFF manages bond order using interatomic distances. It should also be noted that these geometries are not equilibrium geometry for the reasons mentioned for valency.

Table 1 summarizes the various intermediate states leading to the final products $\mathrm{CO}, \mathrm{C}_{2} \mathrm{H}_{2}$ and $\mathrm{NH}_{3}$.

Table 1: Various paracetamol intermediates during heating in water $+10 \%$ hydroxyl radical.

\begin{tabular}{|c|c|c|c|}
\hline $\begin{array}{c}\text { Degradation } \\
\text { product }\end{array}$ & $\begin{array}{c}\text { Chemical Formula } \\
\text { Time } \mathrm{t} \\
\text { Temperature } \mathrm{T}\end{array}$ & $\begin{array}{l}\text { Degradation } \\
\text { product }\end{array}$ & $\begin{array}{c}\text { Chemical Formula } \\
\text { Time } \mathrm{t} \\
\text { Temperature } \mathrm{T}\end{array}$ \\
\hline & $\begin{array}{c}\mathrm{C}_{8} \mathrm{H}_{9} \mathrm{NO}_{2} \\
0 \mathrm{~ns} \\
300 \mathrm{~K}\end{array}$ & & $\begin{array}{c}\mathrm{C}_{6} \mathrm{H}_{2} \mathrm{O}_{2} \\
4.4 \mathrm{~ns} \\
2445 \mathrm{~K}\end{array}$ \\
\hline & $\begin{array}{c}\mathrm{C}_{8} \mathrm{H}_{6} \mathrm{NO}_{2} \\
1 \mathrm{~ns} \\
575 \mathrm{~K}\end{array}$ & $00-00000$ & $\begin{array}{c}\mathrm{C}_{5} \mathrm{HO} \\
4.5 \mathrm{~ns} \\
2500 \mathrm{~K}\end{array}$ \\
\hline & $\begin{array}{c}\mathrm{C}_{8} \mathrm{H}_{6} \mathrm{NO}_{3} \\
2 \mathrm{~ns} \\
1125 \mathrm{~K}\end{array}$ & $\rightarrow-\infty-a$ & $\begin{array}{l}\mathrm{C}_{4} \mathrm{H}_{2} \mathrm{O} \\
4.57 \mathrm{~ns} \\
2500 \mathrm{~K}\end{array}$ \\
\hline & $\begin{array}{c}\mathrm{C}_{8} \mathrm{NH}_{3} \mathrm{O}_{3} \\
3 \mathrm{~ns} \\
1675 \mathrm{~K}\end{array}$ & $0^{0-c}$ & $\begin{array}{c}\mathrm{C}_{4} \mathrm{H}_{2} \\
4.66 \mathrm{~ns} \\
2500 \mathrm{~K}\end{array}$ \\
\hline \& & $\begin{array}{c}\mathrm{C}_{7} \mathrm{H}_{3} \mathrm{NO}_{2} \\
3.2 \mathrm{~ns} \\
1785 \mathrm{~K}\end{array}$ & $00-0^{2}$ & $\begin{array}{c}\mathrm{C}_{4} \mathrm{H}_{2} \mathrm{O} \\
4.8 \mathrm{~ns} \\
2500 \mathrm{~K}\end{array}$ \\
\hline g & $\begin{array}{c}\mathrm{C}_{6} \mathrm{H}_{4} \mathrm{NO}_{2} \\
3.3 \mathrm{~ns} \\
1840 \mathrm{~K}\end{array}$ & $0-0-0$ & $\begin{array}{c}\mathrm{C}_{3} \mathrm{H}_{2} \\
4.84 \mathrm{~ns} \\
2500 \mathrm{~K}\end{array}$ \\
\hline
\end{tabular}




\begin{tabular}{|c|c|c|c|}
\hline & $\mathrm{C}_{6} \mathrm{H}_{2} \mathrm{NO}$ & & $\mathrm{C}_{3} \mathrm{HO}$ \\
& $3.4 \mathrm{~ns}$ & 0.00 & $4.86 \mathrm{~ns}$ \\
& $1895 \mathrm{~K}$ & & $2500 \mathrm{~K}$ \\
\hline & $\mathrm{C}_{6} \mathrm{HNO}$ & & $\mathrm{C}_{3} \mathrm{H}_{2} \mathrm{O}$ \\
& $3.5 \mathrm{~ns}$ & $80-0$ & $4.87 \mathrm{~ns}$ \\
& 1950 & & $2500 \mathrm{~K}$ \\
\hline & $\mathrm{C}_{6} \mathrm{HO}_{2}+\mathrm{NH}_{3}$ & & $\mathrm{C}_{2} \mathrm{H}_{2}$ \\
& $3.9 \mathrm{~ns}$ & & $4.90 \mathrm{~ns}$ \\
& $2170 \mathrm{~K}$ & & $2500 \mathrm{~K}$ \\
\hline
\end{tabular}

To check that there was no time delay, constant temperature simulations were carried out at $1600 \mathrm{~K}$ and $2500 \mathrm{~K}$ during $5 \mathrm{~ns}$, with the same parameters. The system is equilibrated at 1600 $\mathrm{K}$ during the first $0.5 \mathrm{~ns}$, i.e. without reactions between species. At $1600 \mathrm{~K}$ only $2 \mathrm{CO}$ molecules are created between 1.5 and $1.6 \mathrm{~ns}$. A 5-carbon membered ring is also created, as displayed in Table 2. No further evolution was observed after $1.6 \mathrm{~ns}$.

Table 2: Paracetamol degradation at $1600 \mathrm{~K}$ in water $+10 \%$ hydroxyl radical.

\begin{tabular}{|c|c|c|c|}
\hline $\begin{array}{c}\text { Degradation } \\
\text { product }\end{array}$ & $\begin{array}{c}\text { Chemical Formula } \\
\text { Time t }\end{array}$ & $\begin{array}{c}\text { Degradation } \\
\text { product }\end{array}$ & $\begin{array}{c}\text { Chemical Formula } \\
\text { Time t }\end{array}$ \\
\hline & $\begin{array}{c}\mathrm{C}_{8} \mathrm{H}_{3} \mathrm{O}_{3} \mathrm{~N} \\
0.54 \mathrm{~ns}\end{array}$ & & $\begin{array}{c}\mathrm{C}_{7} \mathrm{H}_{4} \mathrm{NO}_{3} \\
1.5 \mathrm{~ns}\end{array}$ \\
\hline & $\begin{array}{c}\mathrm{C}_{6} \mathrm{H}_{4} \mathrm{NO}_{4} \\
0.6 \mathrm{~ns}\end{array}$ & & $\begin{array}{c}\mathrm{C}_{6} \mathrm{H}_{4} \mathrm{NO}_{2} \\
1.6 \mathrm{~ns}\end{array}$ \\
\hline
\end{tabular}

At $2500 \mathrm{~K}$, paracetamol degradation leads to $2 \mathrm{CO}$ molecules and $\mathrm{NH}_{3}$ at $\mathrm{t}=0.51 \mathrm{~ns}$ just after the end of the equilibrium period. Four additional $\mathrm{CO}$ molecules are produced successively at $0.6,0.7,1.3$ and $2.5 \mathrm{~ns} . \mathrm{C}_{2} \mathrm{H}_{2}$ is simultaneously created with the $6^{\text {th }} \mathrm{CO}$ at $2.47 \mathrm{~ns}$. Since no further evolution occurs up to $5 \mathrm{~ns}$, this means that a higher local equivalent temperature is required for full conversion towards $\mathrm{CO}_{2}, \mathrm{H}_{2}$ and $\mathrm{NO}_{\mathrm{x}}$. 
These constant temperature simulations validate the simulations with the chosen temperature ramp. The heating rate $(0.55 \mathrm{~K} / \mathrm{ps})$ selected is thus slow enough to obtain the $\mathrm{CO}$ formation steps at a similar temperature to that obtained for the constant temperature simulation.

The present simulation methodology enables an "equivalent local temperature" to be reached that allows the decomposition of organic molecules in water activated by a fraction of oxidizing radicals ( $\mathrm{HO}^{\bullet}$ here). In fact, if the local equivalent temperature is high, while the overall temperature remains at $300 \mathrm{~K}$, as for plasma discharges (He jets, dielectric barrier discharges) above liquid [12, 6-8, 49], the effects of the missing $\mathrm{H}_{2} \mathrm{O}$ molecules required to reach an experimental $\left[\mathrm{HO}^{*}\right] /\left[\mathrm{H}_{2} \mathrm{O}\right]$ ratio of $10^{-6}$ are captured by the thermostat controlling the temperature, both for ramp and constant temperature simulations. These simulations do not inform about the form of the equivalent temperature source but suggests that the observed degradation step requires a source that provides effects such as an "equivalent temperature". This can be of help in experiments: recording by-products will inform about local energetics when using MD simulations.

The present simulations thus offer a methodology for interpreting local reactions leading to by-products, whatever the experimental technique. In the case of plasma water treatment, the difficulty lies in identifying the local temperature source. It may stem from the reaction heat during bond formation and breaking which can lead locally to a net energy release, or from the plasma source itself in the liquid affected zone. On the experimental side, it should be noted that $\mathrm{OH}^{*}$ attack either on the aromatic ring or on the functional groups was observed. Ring opening is also frequently reported in advanced oxidation process studies at ambient temperature $[6,7,58,59]$.

\section{Conclusion}


An MD simulation methodology implementing a temperature ramp has been developed in order to unravel the degradation products of organic molecules in water in the presence of an active radical. It was applied to the degradation of paracetamol in the presence of $\mathrm{HO}^{\circ}$ radical. The ratios of the various initial species were rationalized by including the conditions of plasma treatment of water. The temperature increase aimed to simulate a local source of energy delivered into the simulation box. Predicting the degradation intermediates enabled the possible appearance of harmful compounds during treatment to be detected. This can be avoided either by prolonging the treatment time, or by adjusting the experimental parameters accordingly. Conversely, MD simulations provided an idea of the local conditions that need to be reached in order to obtain partial or full degradation of the treated molecules.

A direct comparison of the results obtained in this work to experimental ones will be very useful in order to validate the approach as a powerful predictive tool for the degradation of organic pollutants by plasma and, more generally, by AOPs. However, this task remains highly challenging since most of the compounds identified in the simulations are unlikely to be detected by analytical techniques due to their transient nature.

\section{Acknowledgements}

Dr. Corina Bradu is gratefully acknowledged for stimulating discussions and for her critical reading of the manuscript. Campus France is gratefully acknowledged for the grant PHC BRANCUSI 2019 \#43505RC.

\section{Data Availability Statement}

The data supporting the findings of this study are available upon reasonable request. 


\section{References}

[1] D. Kolpin, M. Skopec, M. Meyer, E. Furlong, S. Zaugg, Sci. Total Environ. 328, 119 (2004)

[2] Å. Bergman, J. J. Heindel, S. Jobling, K. A. Kidd and R. T. Zoeller (Eds) State of the science of Endocrine Disrupting Chemicals, United Nations Environment Program and World Health Organization (2012). Available at URL:

https://www.unenvironment.org/resources/report/state-science-endocrine-disrupting$\underline{\text { chemicals }}$

[3] D. M. Kristensen, U. Hass, L. Lesne, G. Lottrup, P. R. Jacobsen, C. DesdoitsLethimonier, J. Boberg, J. H. Petersen, J. Toppari, T. K. Jensen, S. Brunak, N. E. Skakkebaek, C. Nellemann, K. M. Main, B. Jegou, H. Leffers, Intrauterine exposure to mild analgesics is a risk factor for development of male reproductive disorders in human and rat, Human Reproduction, 26, 235 (2011)

[4] International Panel on Chemical Pollution, Worldwide initiatives to identify endocrine disrupting chemicals (EDCs) and potential EDCs, United Nation Environment Program (2017). Available at URL: https://wedocs.unep.org/handle/20.500.11822/25633?show=full [5] M. Magureanu, N. B. Mandache, V. I. Parvulescu, Degradation of pharmaceutical compounds in water by non-thermal plasma treatment, Water Research 81, 124-136 (2015) [6] Y. Baloul, O. Aubry, H. Rabat, C. Colas, B. Maunit, D. Hong, Paracetamol degradation in aqueous solution by non-thermal plasma, Eur. Phys. J. Appl. Phys. 79, 30802 (2017)

[7] N. Korichi, O. Aubry, H. Rabat, B. Cagnon, D. Hong, Paracetamol Degradation by Catalyst Enhanced Non-Thermal Plasma Process for a Drastic Increase in the Mineralization Rate, Catalysts, 10, 959 (2020) 
[8] M. Magureanu, N. B. Mandache, C. Bradu, V. I. Parvulescu, High efficiency plasma treatment of water contaminated with organic compounds. Study of the degradation of ibuprofen, Plasma Process. Polym. 15, e1700201 (2018)

[9] P. Vanraes, A. Y. Nikiforov, C. Leys, Electrical Discharge in Water Treatment Technology for Micropollutant Decomposition, in Plasma Science and Technology - Progress in Physical States and Chemical Reactions (InTech, 2016)

[10] I. Adamovich, S. D. Baalrud, A. Bogaerts, P. J. Bruggeman., M. Cappelli, V. Colombo, U. Czarnetzki, U. Ebert, J. G. Eden, P. Favia, D. B. Graves, S. Hamaguchi, G. Hieftje, M. Hori, I. D. Kaganovich, U. Kortshagen, M. J. Kushner, N. J. Mason, S. Mazouffre, S. Mededovic Thagard, H.-R. Metelmann, A. Mizuno, E. Moreau, A. B. Murphy, B. A. Niemira, G. S. Oehrlein, Z. Lj. Petrovic, L. C. Pitchford, Y.-K. Pu, S. Rauf, O. Sakai, S. Samukawa, S. Starikovskaia, J. Tennyson, K. Terashima, M. M. Turner, M. C. M. van de Sanden, A. Vardelle, The 2017 Plasma Roadmap: Low temperature plasma science and technology, J. Phys. D: Appl. Phys. 50, 323001 (2017)

[11] Y. Gorbanev and A. Bogaerts, Chemical Detection of Short-Lived Species Induced in Aqueous Media by Atmospheric Pressure Plasma, in Atmospheric Pressure Plasma - From Diagnostics to Applications, Edited by A. Nikiforov and Z. Chen, IntechOpen (2018) DOI: 10.5772/intechopen.79480

[12] J. Bruggeman, M. J. Kushner, B. R. Locke, J. G. E. Gardeniers, W. G. Graham, D. B. Graves, R. C. H. M. Hofman-Caris, D. Maric, J. P. Reid, E. Ceriani, D. Fernandez Rivas, J. E. Foster, S. C. Garrick, Y. Gorbanev, S. Hamaguchi, F. Iza, H. Jablonowski, E. Klimova, J. Kolb, F. Krcma, P. Lukes, Z. Machala, I. Marinov, D. Mariotti, S. Mededovic Thagard, D. Minakata, E. C. Neyts, J. Pawlat, Z. Lj. Petrovic, R. Pflieger, S. Reuter, D. C. Schram, S. Schröter, M. Shiraiwa, B. Tarabová, P. A. Tsai, J. R. R. Verlet, T. von Woedtke, K. R. Wilson, K. Yasui, G. Zvereva, Plasma-liquid interactions: a review and roadmap, Plasma 
Sources Sci. Technol. 25, 053002 (2016)

[13] X. Lu, G. V. Naidis, M. Laroussi, S. Reuter, D.B.Graves, K.Ostrikov, Reactive species in non-equilibrium atmospheric pressure plasmas: Generation, transport, and biological effects, Physics Report. 630, 1 (2016)

[14] Y. Gorbanev, C. C. W. Verlackt, S. Tinck, E. Tuenter, K. Foubert, P. Cos, A. Bogaerts, Combining experimental and modelling approaches to study the sources of reactive species induced in water by the COST RF plasma jet, Physical Chemistry Chemical Physics 20, 2797 (2018)

[15] P. J. Bruggeman, C. Leys, Non-thermal plasmas in and in contact with liquids, J. Phys. D: Appl. Phys. 42, 053001 (2009)

[16] I. Marinov, S. M. Starikowskaia and A. Rousseau, Dynamics of plasma evolution in a nanosecond underwater discharge, J. Phys. D: Appl. Phys. 47, 224017 (2014)

[17] G. Collet, E. Robert, A. Lenoir, M. Vandamme, T. Darny, S. Dozias, C. Kieda, J. M. Pouvesle, Plasma jet-induced tissue oxygenation: potentialities for new therapeutic strategies, Plasma Sources Sci. Technol. 23, 012005 (2014)

[18] B. Jiang, J. Zheng, S. Qiu, M.Wu, Q.Zhang, Z. Yan, Q. Xue, Review on electrical discharge plasma technology for wastewater remediation. Chemical Engineering Journal 236, $348(2014)$

[19] M. Vandamme, E. Robert, S. Lerondel, V. Sarron, D. Ries, S. Dozias, J. Sobilo, ROS implication in a new antitumor strategy based on non-thermal plasma, International Journal of Cancer 130, 2185 (2012)

[20] D. Riès, G. Dilecce, E. Robert, P. F. Ambrico, S. Dozias, J. M. Pouvesle, LIF and fast imaging plasma jet characterization relevant for NTP biomedical applications, J. Phys. D: Appl. Phys. 47, 275401 (2014) 
[21] A. Stancampiano, P. E. Bocanegra, S. Dozias, J. M. Pouvesle, E. Robert, Evidence, origin and impact of liquid flows in plasma medicine in vitro treatments with APPJs Plasma Sources Sci. Technol. 30, 015002 (2021)

[22] A. V. Omran, G. Busco, L. Ridou, S. Dozias, C. Grillon, J. M. Pouvesle, E. Robert, Cold atmospheric single plasma jet for RONS delivery on large biological surfaces, Plasma Sources Sci. Technol. 29, 105002 (2020)

[23] P. Vanraes, and A. Bogaerts, Plasma physics of liquids-A focused review, Appl. Phys. Rev. 5, 031103 (2018)

[24] E. Neyts, P. Brault, Molecular dynamics simulations for plasma surface interactions, Plasma Processes and Polymers 14, 1600145 (2017)

[25] C. C. W. Verlackt, E. C. Neyts, A. Bogaerts, Atomic scale behavior of oxygen-based radicals in water, J. Phys. D: Appl. Phys. 50, 11LT01 (2017)

[26] C. C. W. Verlack, W. Van Boxem, A. Bogaerts, Transport and accumulation of plasma generated species in aqueous solution. Physical Chemistry Chemical Physics 20, 6845-6859 (2018)

[27] M. Yusupov, E. C. Neyts, P. Simon, G. Berdiyorov, R. Snoeckx, A. C. T. van Duin, A. Bogaerts, Reactive molecular dynamics simulations of oxygen species in a liquid water layer of interest for plasma medicine, J. Phys. D: Appl. Phys. 47, 025205 (2014)

[28] S. Xu, V. Jiràsek, P. Lukes, Molecular dynamics simulations of singlet oxygen atoms reactions with water leading to hydrogen peroxide, J. Phys. D: Appl. Phys. 53, 275204 (2020 [29] J. Van der Paal, S. Aernouts, A. C. T. van Duin, E. C. Neyts, A. Bogaerts, Interaction of $\mathrm{O}$ and $\mathrm{OH}$ radicals with a simple model system for lipids in the skin barrier: a reactive molecular dynamics investigation for plasma medicine, J. Phys. D: Appl. Phys. 46, 395201 [30] A. Bogaerts, N. Khosravian, J. Vander Paal, C. C. W. Verlackt, B. Kamaraj, M. Yusupov, E. C. Neyts, Multi-level molecular modelling for plasma medicine, J. Phys. D: 
Appl. Phys. 49, 054002 (2016)

[31] O. Rahaman, A. C. T. van Duin, W. A. Goddard III, D. J. Doren, Development of a ReaxFF reactive force field for glycine and application to solvent effect and tautomerization J. Phys. Chem. B 115, 249 (2011)

[32] A. C. T. van Duin, S. Dasgupta, F. Lorant, W. A. Goddard, ReaxFF: A Reactive Force Field for Hydrocarbons, J. Phys. Chem. A 105, 9396 (2001)

[33] T. P. Sentfle, S. Hong, M. M. Islam, S. B. Kylasa, Y. Zheng, Y. K. Shin, C. Junkermeier, R. Engel-Herbert, M. J. Janik, H. M. Aktulga, T. Verstraelen, A. Grama, A. C. T. van Duin, The ReaxFF reactive force-field: development, applications and future directions, $n p j$ Computational Materials 2, 15011 (2016)

[34] T. Liang, Y. K. Shin, D. E. Yilmaz, K. G. Vishnu, O. Verners, C. Zou, S. R. Phillpot, S. B. Sinnot, A. C. T. van Duin, Reactive potentials for advanced atomistic potentials, Ann. Review of Materials Research 43, 109 (2013)

[35] S. Yang, T. Zhao, J. Cui, Z. Han, L. Zou, X. Wang, Y. Zhang, Molecular dynamics simulations of the interaction between $\mathrm{OH}$ radicals in plasma with poly- $\beta-1-6-\mathrm{N}-$ acetylglucosamine, Plasma Sci. Technol. 22, 125401 (2020) [36] M. Yusupov, E. C. Neyts, U. Khalilov, R. Snoeckx, A. C. T. van Duin, A. Bogaerts, Atomic-scale simulations of reactive oxygen plasma species interacting with bacterial cell walls, New J. Phys. 14, 093043 (2012)

[37] M. Yusupov, A. Bogaerts, S. Huygh, R. Snoeckx, A. C. T. van Duin, and E. C. Neyts, Plasma-Induced Destruction of Bacterial Cell Wall Components: A Reactive Molecular Dynamics Simulation, J. Phys. Chem. C 117, 5993 (2013)

[38] M. Yusupov, E. C. Neyts, C. C. Verlackt, U. Khalilov, A. C. T. van Duin, A. Bogaerts, Inactivation of the Endotoxic Biomolecule Lipid A by Oxygen Plasma Species: A Reactive Molecular Dynamics Study, Plasma Processes Polym. 12, 162 (2015) 
[39] E. C. Neyts, M. Yusupov, C. C. Verlackt, A. Bogaerts, Computer simulations of plasmabiomolecule and plasma-tissue interactions for a better insight in plasma medicine, J. Phys. D: Appl. Phys. 47293001 (2014)

[40] A. Bogaerts, M. Yusupov, J. Van der Paal, C. C. W. Verlackt, E. C. Neyts, Reactive Molecular Dynamics Simulations for a Better Insight in Plasma Medicine, Plasma Processes Polym. 11, 1156 (2014)

[41] S. G. Srinivasan, A. C. T. van Duin, P. Ganesh, Development of a ReaxFF Potential for Carbon Condensed Phases and Its Application to the Thermal Fragmentation of a Large Fullerene. J. Phys. Chem. A 119, 571 (2015)

[42] K. Chenoweth, A. C. T. van Duin, W. A. Goddard, ReaxFF Reactive Force Field for Molecular Dynamics Simulations of Hydrocarbon Oxidation, J. Phys. Chem. A, 112, 1040 (2008)

[43] B.; Schatz, G. C. Carbonization in Polyacrylonitrile (PAN) Based Carbon Fibers Studied by ReaxFF Molecular Dynamics Simulations. J. Phys. Chem. B 116, 4684 (2012)

[44] B. Saha, G. C. Schatz, Carbonization in Polyacrylonitrile (PAN) Based Carbon Fibers Studied by ReaxFF Molecular Dynamics Simulations. J. Phys. Chem. B 116, 4684 (2012) [45] M. Kowalik, C. Ashraf, B. Damirchi, D. Akbarian, S. Rajabpour, A. C. T. van Duin, Atomistic Scale Analysis of the Carbonization Process for C/H/O/N-Based Polymers with the ReaxFF Reactive Force Field, J. Phys. Chem. B 123, 5357 (2019)

[46] C. Ashraf, A. Jain, Y. Xuan, A. C. T. van Duin, ReaxFF Based Molecular Dynamics Simulations of Ignition Front Propagation in Hydrocarbon/Oxygen Mixtures under High Temperature and Pressure Conditions, Phys. Chem. Chem. Phys. 19, 5004 (2017)

[47] C. Ashraf, S. Shabnam, A. Jain, Y. Xuan, A. C. T. van Duin, Pyrolysis of Binary Fuel Mixtures at Supercritical Conditions: A ReaxFF Molecular Dynamics Study, Fuel 235, 194 (2019) 
[48] L. Martínez, R. Andrade, E. G. Birgin, J. M. Martínez. Packmol: A package for building initial configurations for molecular dynamics simulations. Journal of Computational Chemistry 30, 2157 (2009)

[49] C. Bradu, K. Kutasi, M. Magureanu, N. Pua and S. Živkovi, Reactive nitrogen species in plasma-activated water: generation, chemistry and application in agriculture, J. Phys. D: Appl. Phys. 53, 223001 (2020)

[50] P. Bruggeman and D.C. Schram, On OH production in water containing atmospheric pressure plasmas, Plasma Sources Sci. Technol. 19, 045025 (2010)

[51] Q. Xiong, Z. Yang, P. J. Bruggeman, Absolute OH density measurements in an atmospheric pressure dc glow discharge in air with water electrode by broadband UV absorption spectroscopy, J. Phys. D: Appl. Phys. 48, 424008 (2015)

[52] A. Nikiforov, Q. Xiong, N. Britun, R. Snyders, X. P. Lu, C. Leys, Absolute Concentration of OH Radicals in Atmospheric Pressure Glow Discharges with a Liquid Electrode Measured by Laser-Induced Fluorescence Spectroscopy, Applied Physics Express 4, $026102(2011)$

[53] Y. Du, G. Nayak, G. Oinuma, Z. Peng, P.J. Bruggeman, Effect of water vapor on plasma morphology, $\mathrm{OH}$ and $\mathrm{H}_{2} \mathrm{O}_{2}$ production in $\mathrm{He}$ and $\mathrm{Ar}$ atmospheric pressure dielectric barrier discharges, J. Phys. D: Appl. Phys. 50 (2017) 145201

[54] S. Plimpton, Fast parallel algorithms for short-range molecular dynamics, J. Comp. Phys. 117, $1(1995)$

[55] Available at URL: http://lammps.sandia.gov

[56] G. te Velde, F.M. Bickelhaupt, E.J. Baerends, C. Fonseca Guerra, S.J.A. van Gisbergen, J.G. Snijders and T. Ziegler, Chemistry with ADF, Journal of Computational Chemistry, 22, $931(2001)$ 
[57] ADF 2019.3 and AMS 2020.1, SCM, Theoretical Chemistry, Vrije Universiteit, Amsterdam, The Netherlands, http://www.scm.com.

[58] E. Moctezuma, E. Leyva, C. A. Aguilar, R. A. Luna, C. Montalvo, Photocatalytic degradation of paracetamol: Intermediates and total reaction mechanism, J. Hazard. Mater. 243, $130(2012)$

[59] M. Neamţu, M. Bobu , A. Kettrup, I. Siminiceanu, Ozone photolysis of paracetamol in aqueous solution, J. Environ. Sci. Heal. Part A 48, 1264 (2013) 


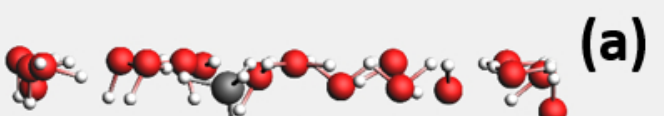

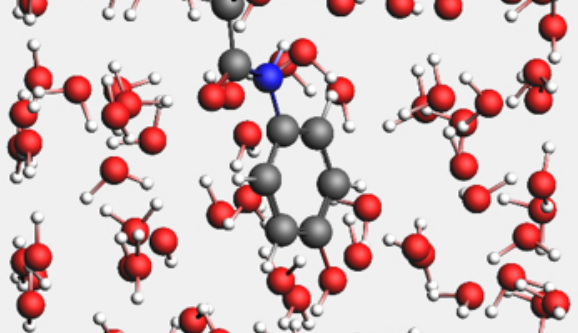
- Ea a a do

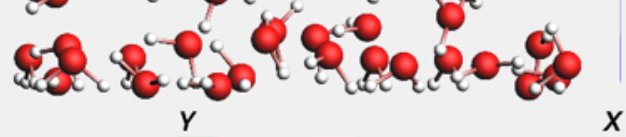

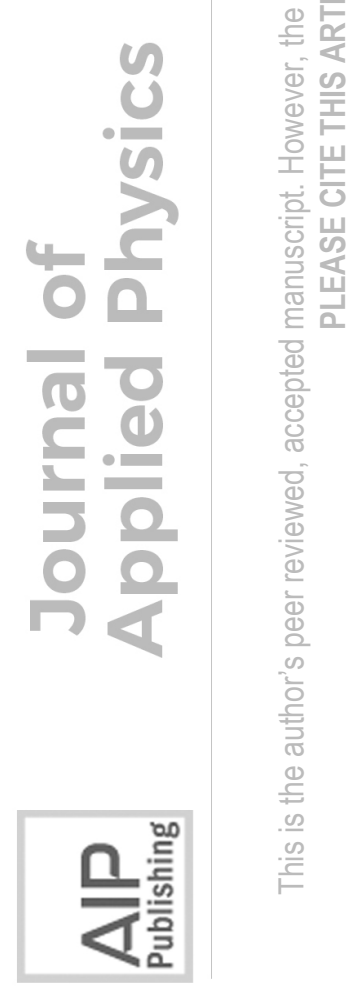




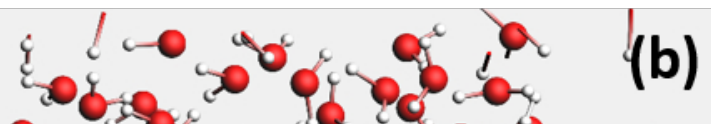
a z a de
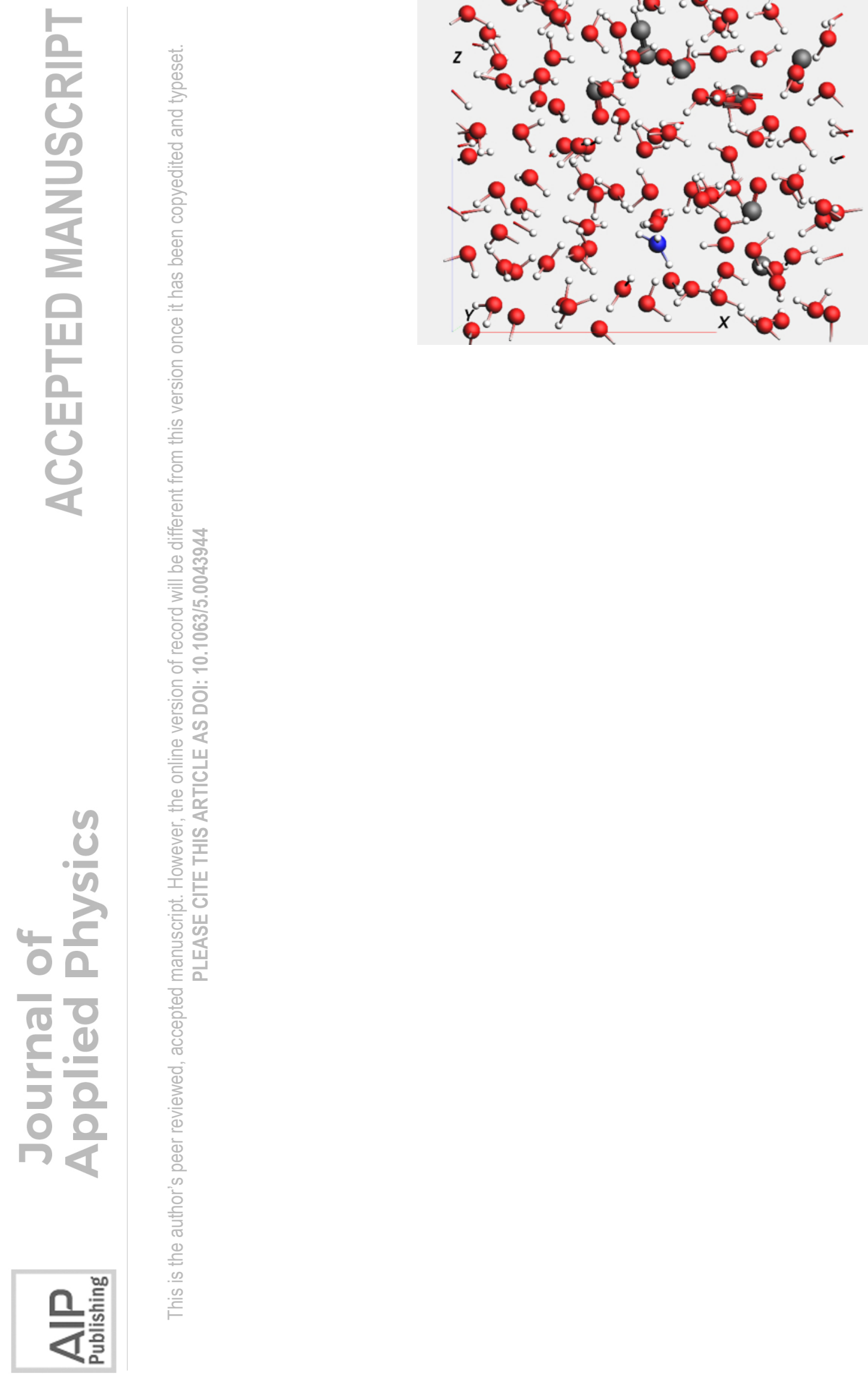


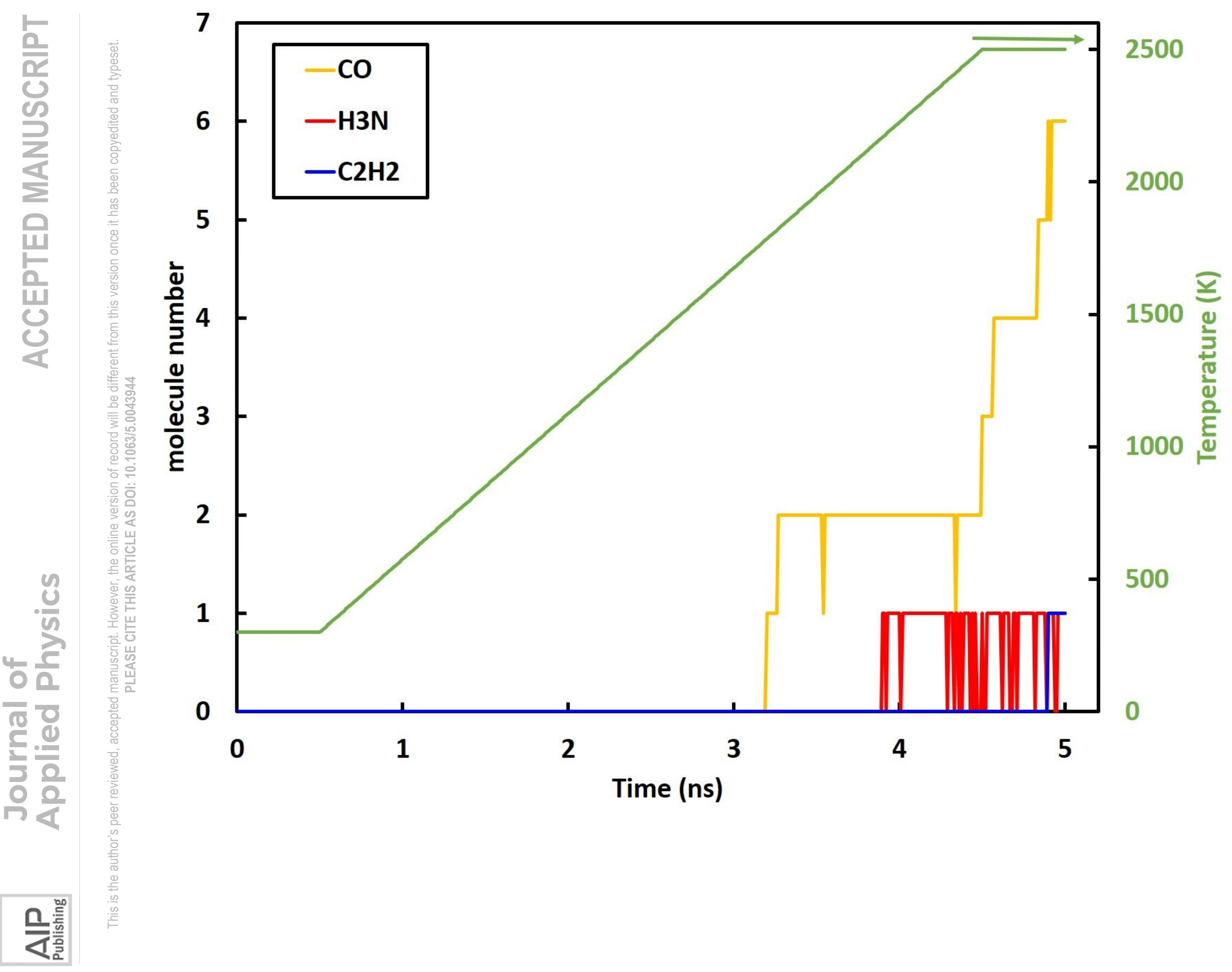




\begin{tabular}{|c|c|c|c|}
\hline $\begin{array}{c}\text { Degradation } \\
\text { product }\end{array}$ & $\begin{array}{c}\text { Chemical Formula } \\
\text { Time } \mathrm{t} \\
\text { Temperature } \mathrm{T}\end{array}$ & $\begin{array}{c}\text { Degradation } \\
\text { product }\end{array}$ & $\begin{array}{c}\text { Chemical Formula } \\
\text { Time t } \\
\text { Temperature T }\end{array}$ \\
\hline & $\begin{array}{c}\mathrm{C}_{8} \mathrm{H}_{9} \mathrm{NO}_{2} \\
0 \mathrm{~ns} \\
300 \mathrm{~K}\end{array}$ & & $\begin{array}{l}\mathrm{C}_{6} \mathrm{H}_{2} \mathrm{O}_{2} \\
4.4 \mathrm{~ns} \\
2445 \mathrm{~K}\end{array}$ \\
\hline & $\begin{array}{c}\mathrm{C}_{8} \mathrm{H}_{6} \mathrm{NO}_{2} \\
1 \mathrm{~ns} \\
575 \mathrm{~K}\end{array}$ & $0-0-0-0$ & $\begin{array}{c}\mathrm{C}_{5} \mathrm{HO} \\
4.5 \mathrm{~ns} \\
2500 \mathrm{~K}\end{array}$ \\
\hline & $\begin{array}{c}\mathrm{C}_{8} \mathrm{H}_{6} \mathrm{NO}_{3} \\
2 \mathrm{~ns} \\
1125 \mathrm{~K}\end{array}$ & $-0-a-a$ & $\begin{array}{l}\mathrm{C}_{4} \mathrm{H}_{2} \mathrm{O} \\
4.57 \mathrm{~ns} \\
2500 \mathrm{~K}\end{array}$ \\
\hline & $\begin{array}{c}\mathrm{C}_{8} \mathrm{NH}_{3} \mathrm{O}_{3} \\
3 \mathrm{~ns} \\
1675 \mathrm{~K}\end{array}$ & & $\begin{array}{c}\mathrm{C}_{4} \mathrm{H}_{2} \\
4.66 \mathrm{~ns} \\
2500 \mathrm{~K}\end{array}$ \\
\hline 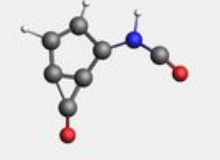 & $\begin{array}{c}\mathrm{C}_{7} \mathrm{H}_{3} \mathrm{NO}_{2} \\
3.2 \mathrm{~ns} \\
1785 \mathrm{~K}\end{array}$ & $000^{\circ}$ & $\begin{array}{c}\mathrm{C}_{4} \mathrm{H}_{2} \mathrm{O} \\
4.8 \mathrm{~ns} \\
2500 \mathrm{~K}\end{array}$ \\
\hline 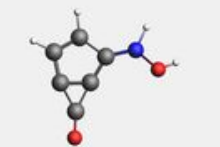 & $\begin{array}{c}\mathrm{C}_{6} \mathrm{H}_{4} \mathrm{NO}_{2} \\
3.3 \mathrm{~ns} \\
1840 \mathrm{~K}\end{array}$ & $-0-0$ & $\begin{array}{c}\mathrm{C}_{3} \mathrm{H}_{2} \\
4.84 \mathrm{~ns} \\
2500 \mathrm{~K}\end{array}$ \\
\hline & $\begin{array}{c}\mathrm{C}_{6} \mathrm{H}_{2} \mathrm{NO} \\
3.4 \mathrm{~ns} \\
1895 \mathrm{~K}\end{array}$ & $a_{0}$ & $\begin{array}{l}\mathrm{C}_{3} \mathrm{HO} \\
4.86 \mathrm{~ns} \\
2500 \mathrm{~K}\end{array}$ \\
\hline an & $\begin{array}{c}\mathrm{C}_{6} \mathrm{HNO} \\
3.5 \mathrm{~ns} \\
1950\end{array}$ & c & $\begin{array}{l}\mathrm{C}_{3} \mathrm{H}_{2} \mathrm{O} \\
4.87 \mathrm{~ns} \\
2500 \mathrm{~K}\end{array}$ \\
\hline & $\begin{array}{c}\mathrm{C}_{6} \mathrm{HO}_{2}+\mathrm{NH}_{3} \\
3.9 \mathrm{~ns} \\
2170 \mathrm{~K}\end{array}$ & $\infty$ & $\begin{array}{c}\mathrm{C}_{2} \mathrm{H}_{2} \\
4.90 \mathrm{~ns} \\
2500 \mathrm{~K}\end{array}$ \\
\hline
\end{tabular}




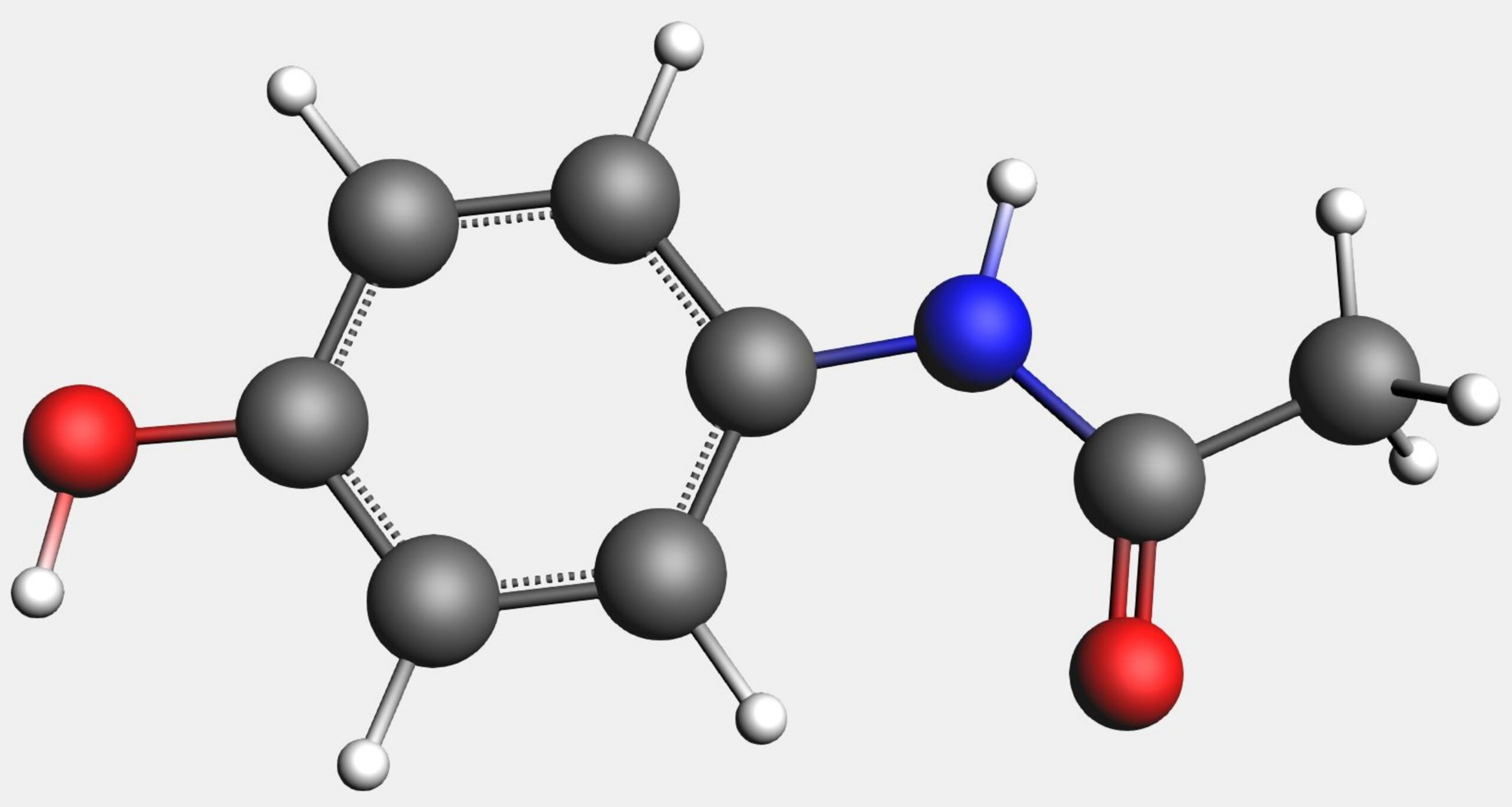




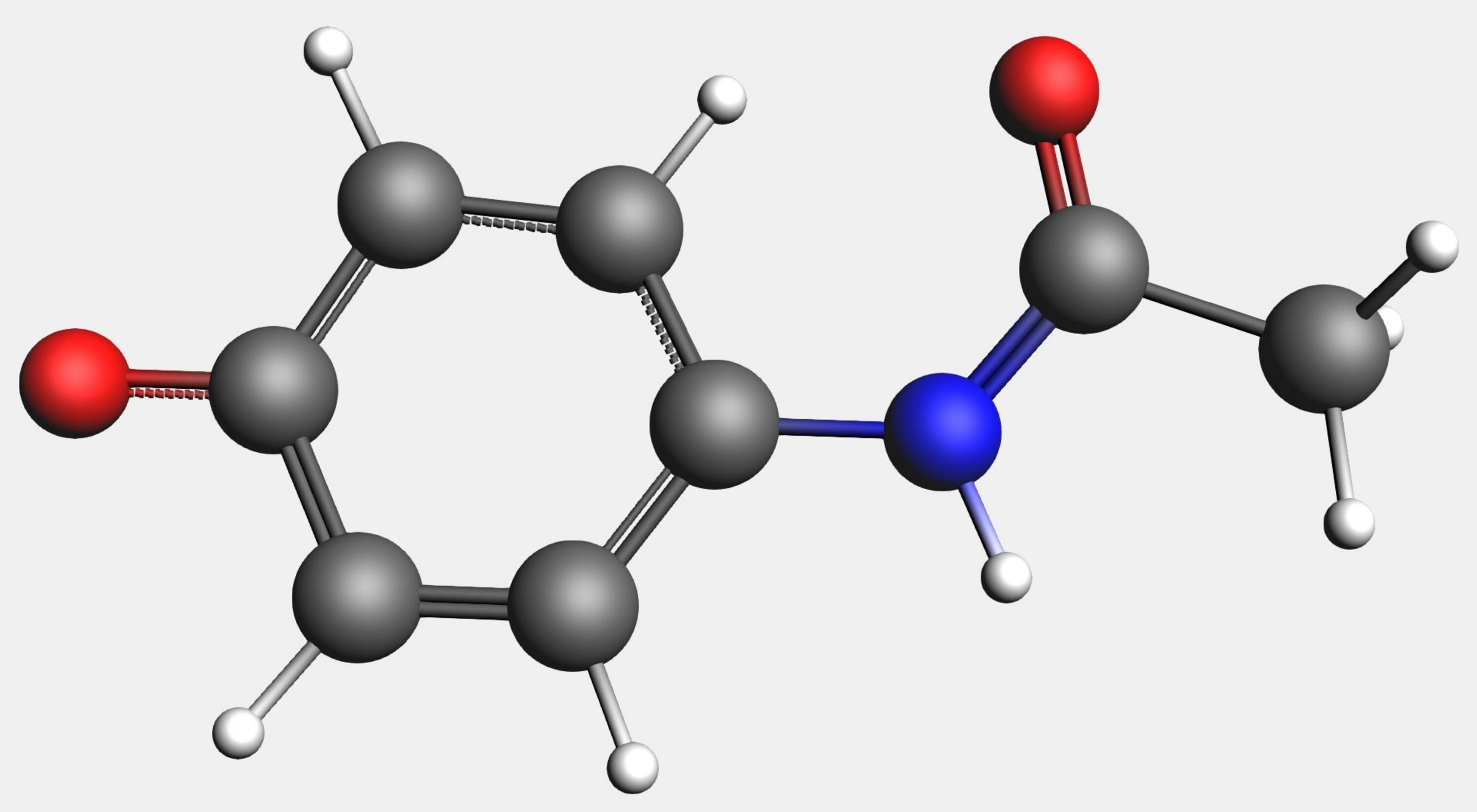




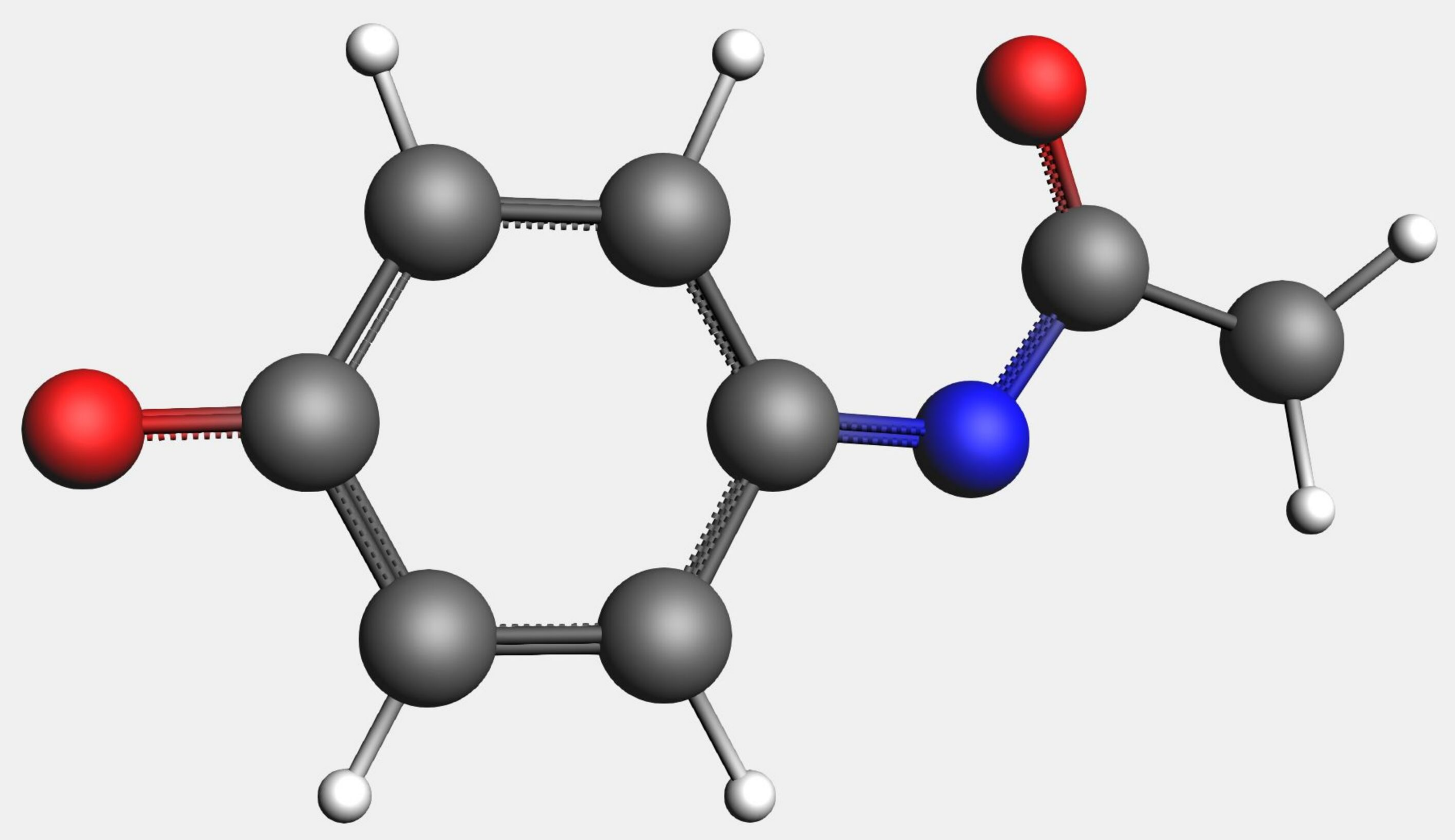




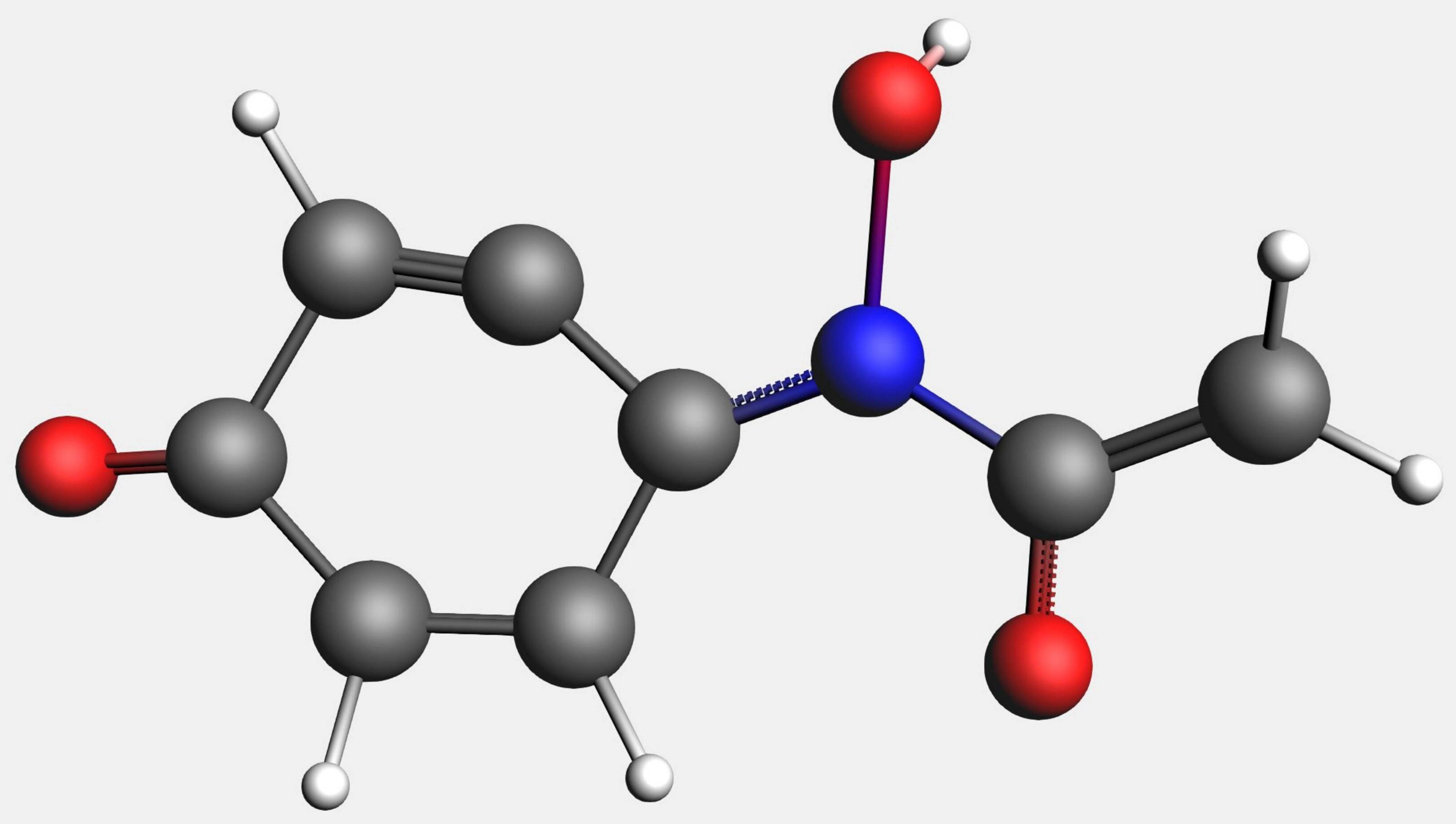




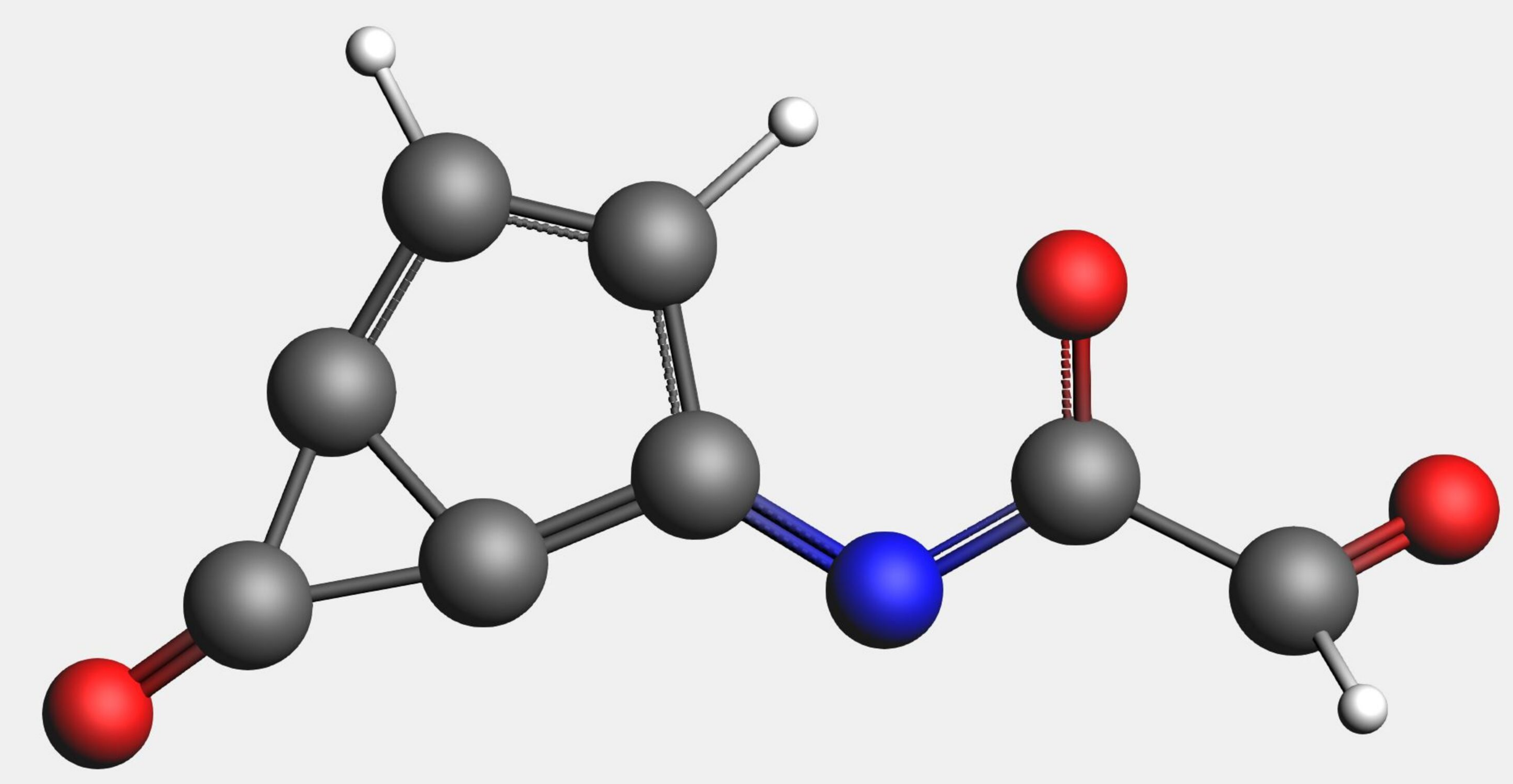




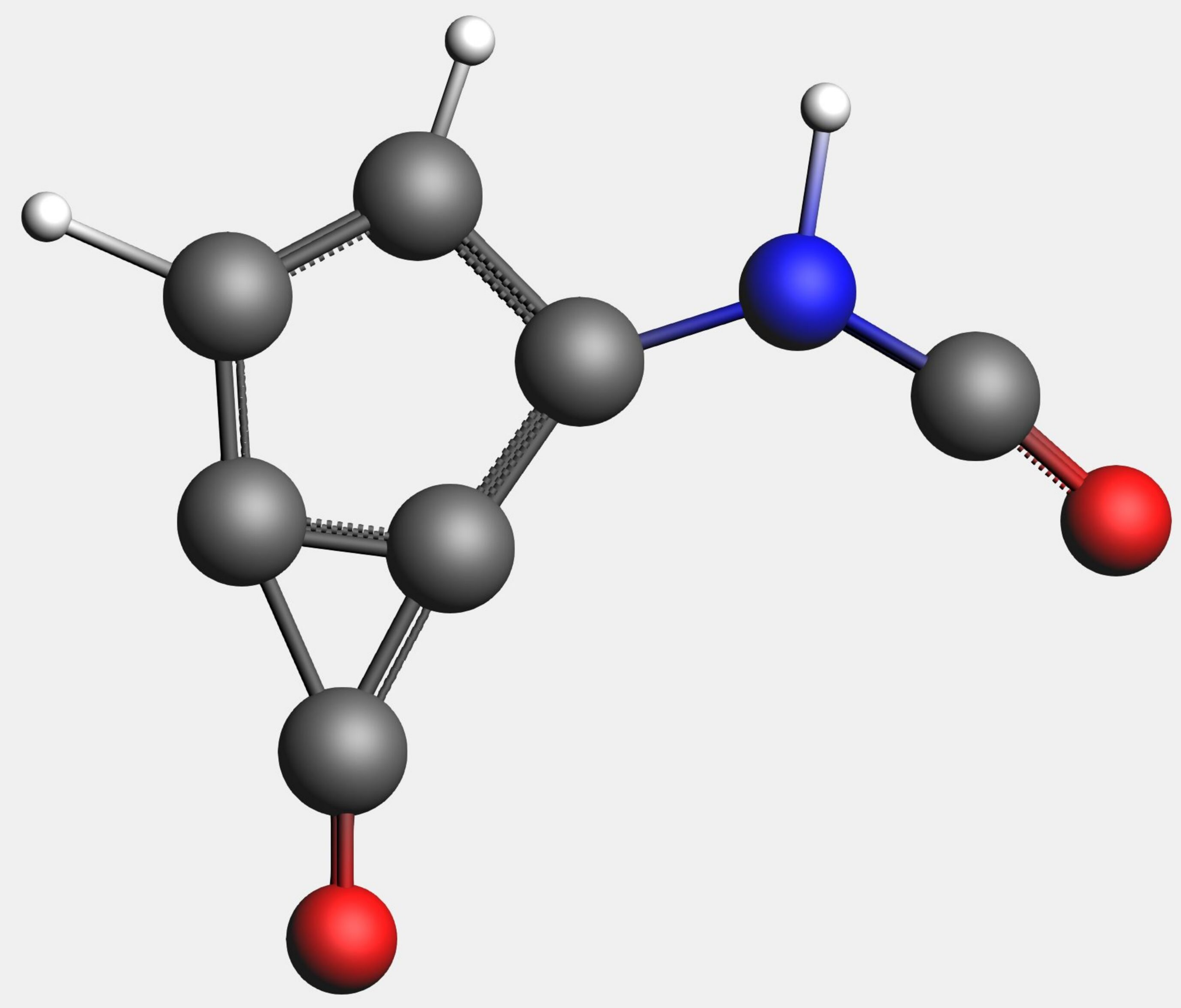




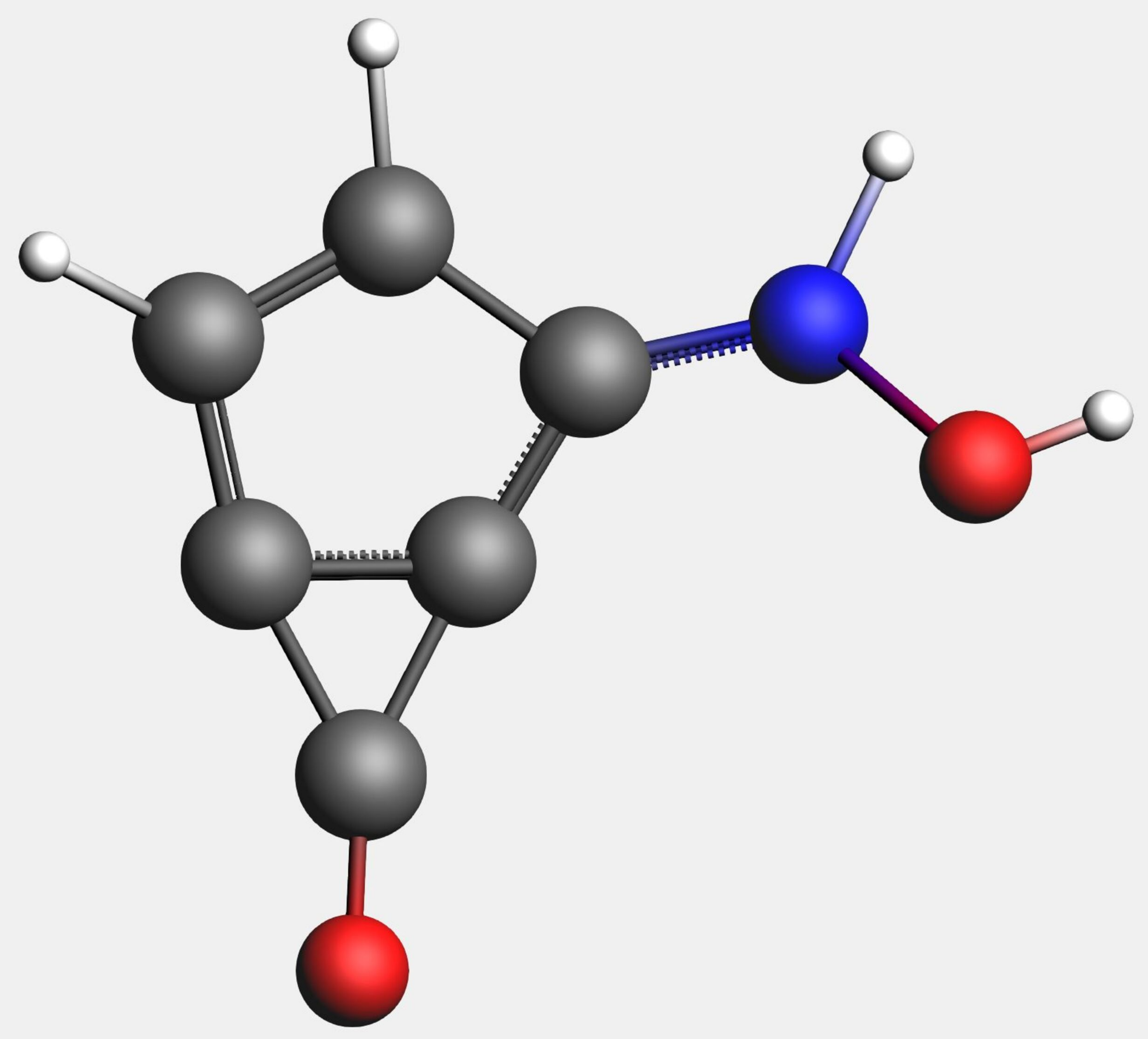




$$
.800 \text {. }
$$




$$
0-000-009
$$




$$
8^{000} \mathrm{ab}_{0}
$$


000000 
-oona 


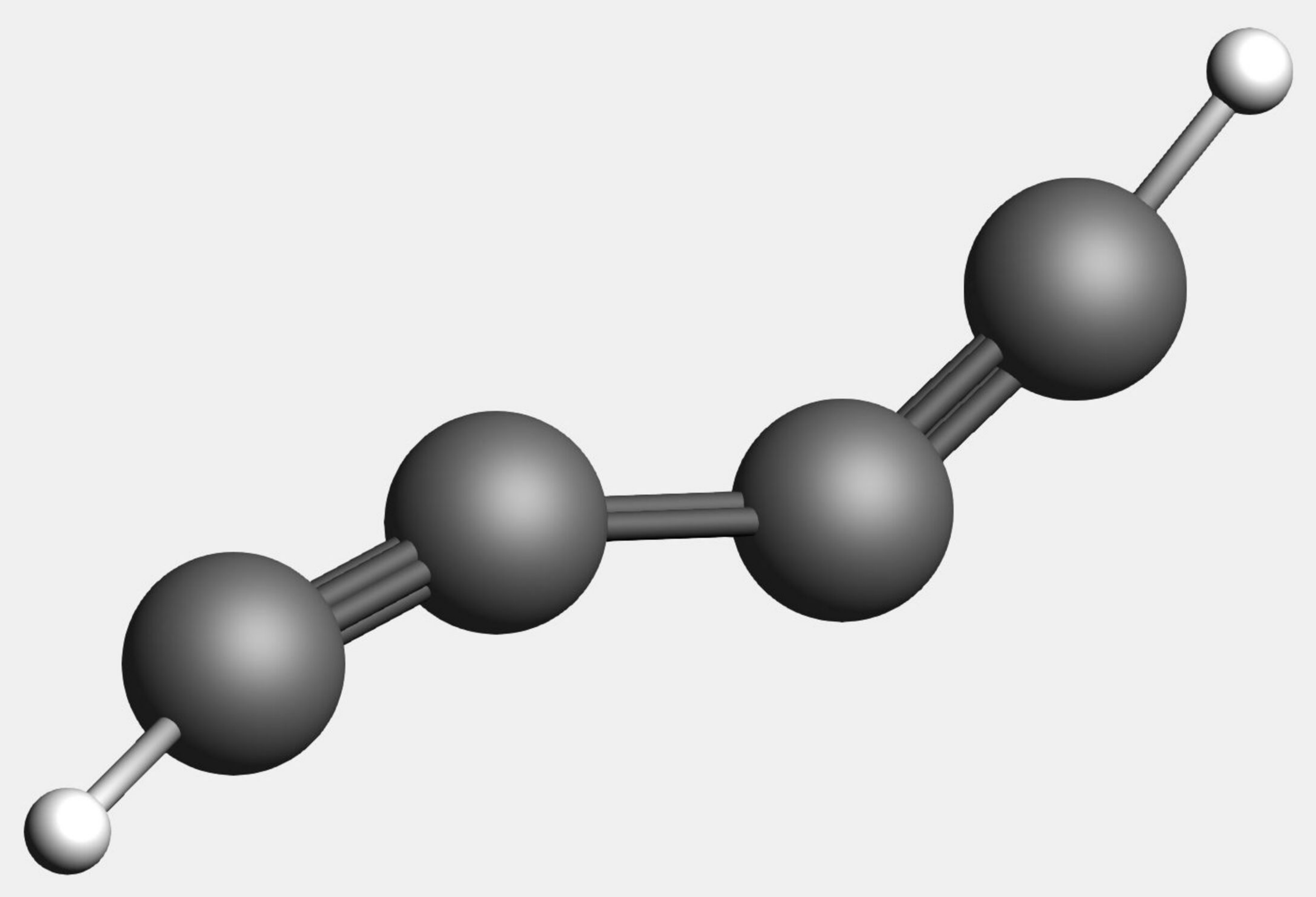




$$
\sum^{\infty}
$$




$$
0.00^{\circ}
$$




$$
000
$$


boos 
0000 
- o. 


\begin{tabular}{|c|c|c|c|}
\hline $\begin{array}{c}\text { Degradation } \\
\text { product }\end{array}$ & $\begin{array}{c}\text { Chemical Formula } \\
\text { Time t }\end{array}$ & $\begin{array}{c}\text { Degradation } \\
\text { product }\end{array}$ & $\begin{array}{c}\text { Chemical Formula } \\
\text { Time t }\end{array}$ \\
\hline & $\begin{array}{c}\mathrm{C}_{8} \mathrm{H}_{3} \mathrm{O}_{3} \mathrm{~N} \\
0.54 \mathrm{~ns}\end{array}$ & & $\begin{array}{c}\mathrm{C}_{7} \mathrm{H}_{4} \mathrm{NO}_{3} \\
1.5 \mathrm{~ns}\end{array}$ \\
\hline & $\begin{array}{c}\mathrm{C}_{6} \mathrm{H}_{4} \mathrm{NO}_{4} \\
0.6 \mathrm{~ns}\end{array}$ & & $\begin{array}{c}\mathrm{C}_{6} \mathrm{H}_{4} \mathrm{NO}_{2} \\
1.6 \mathrm{~ns}\end{array}$ \\
\hline
\end{tabular}

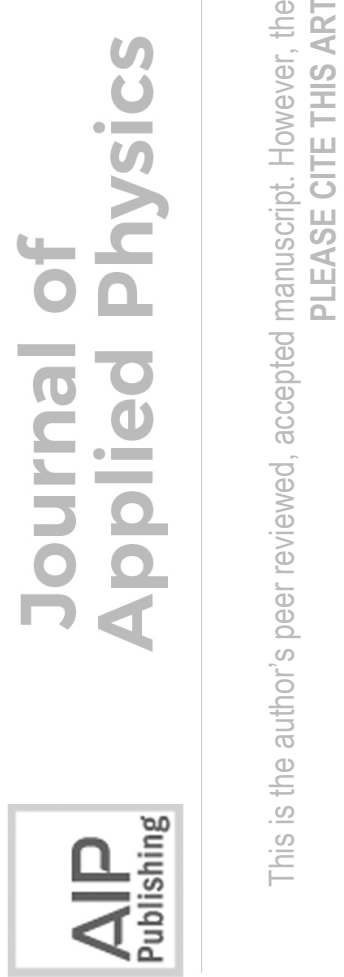




$$
0.00898
$$




$$
x_{0}
$$




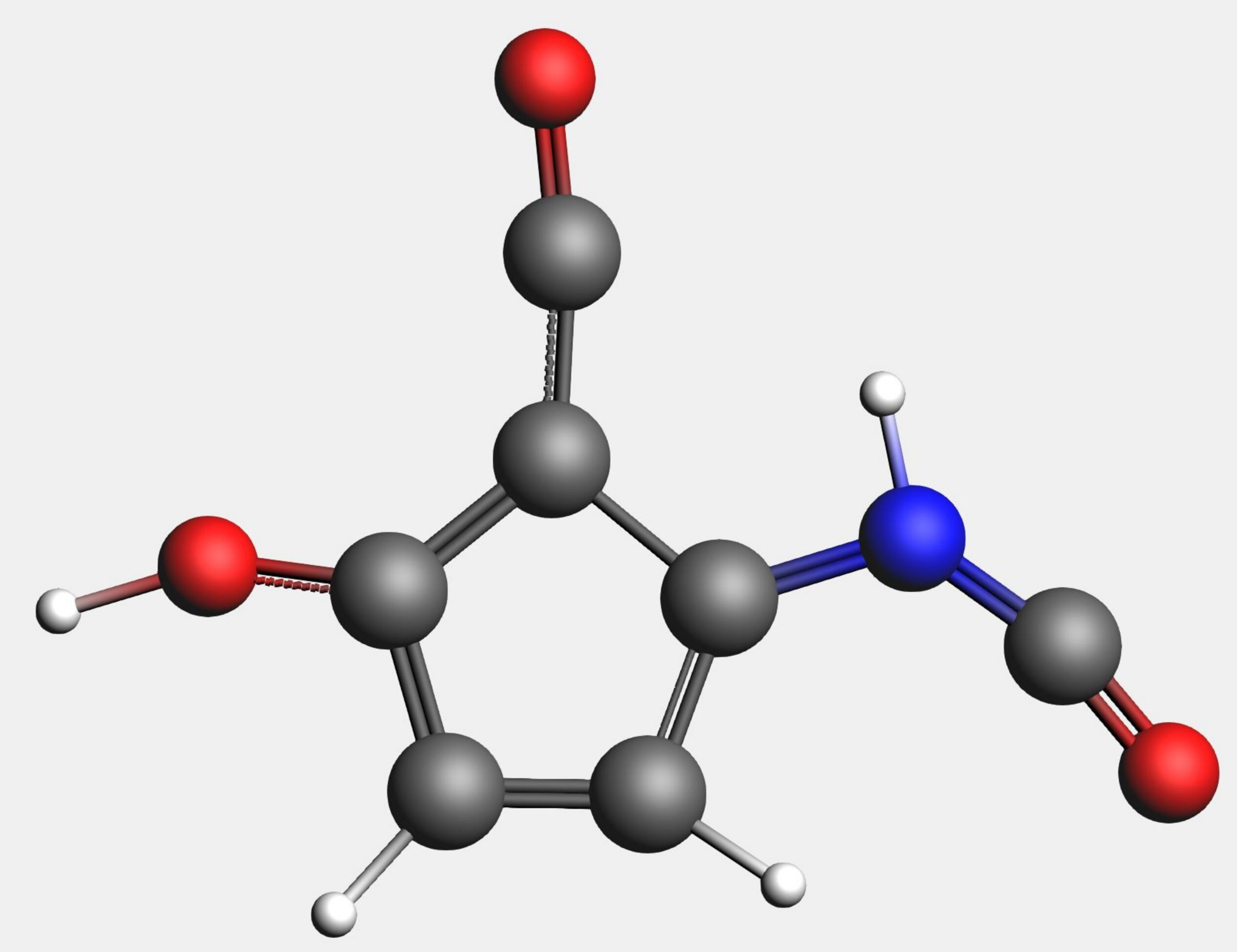




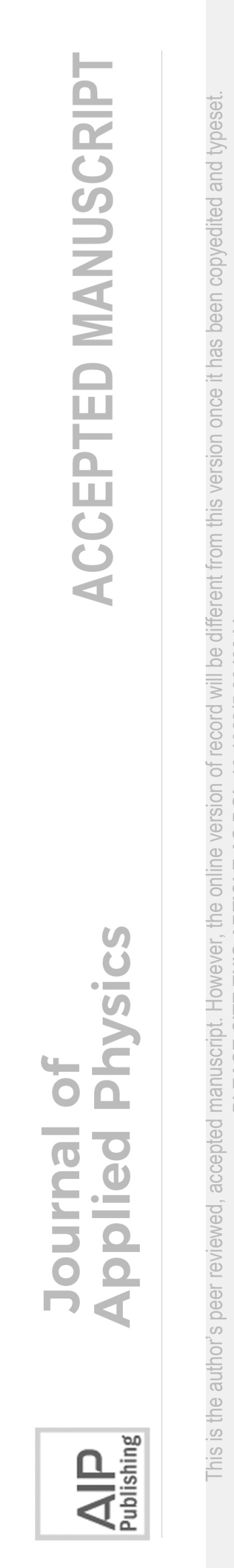

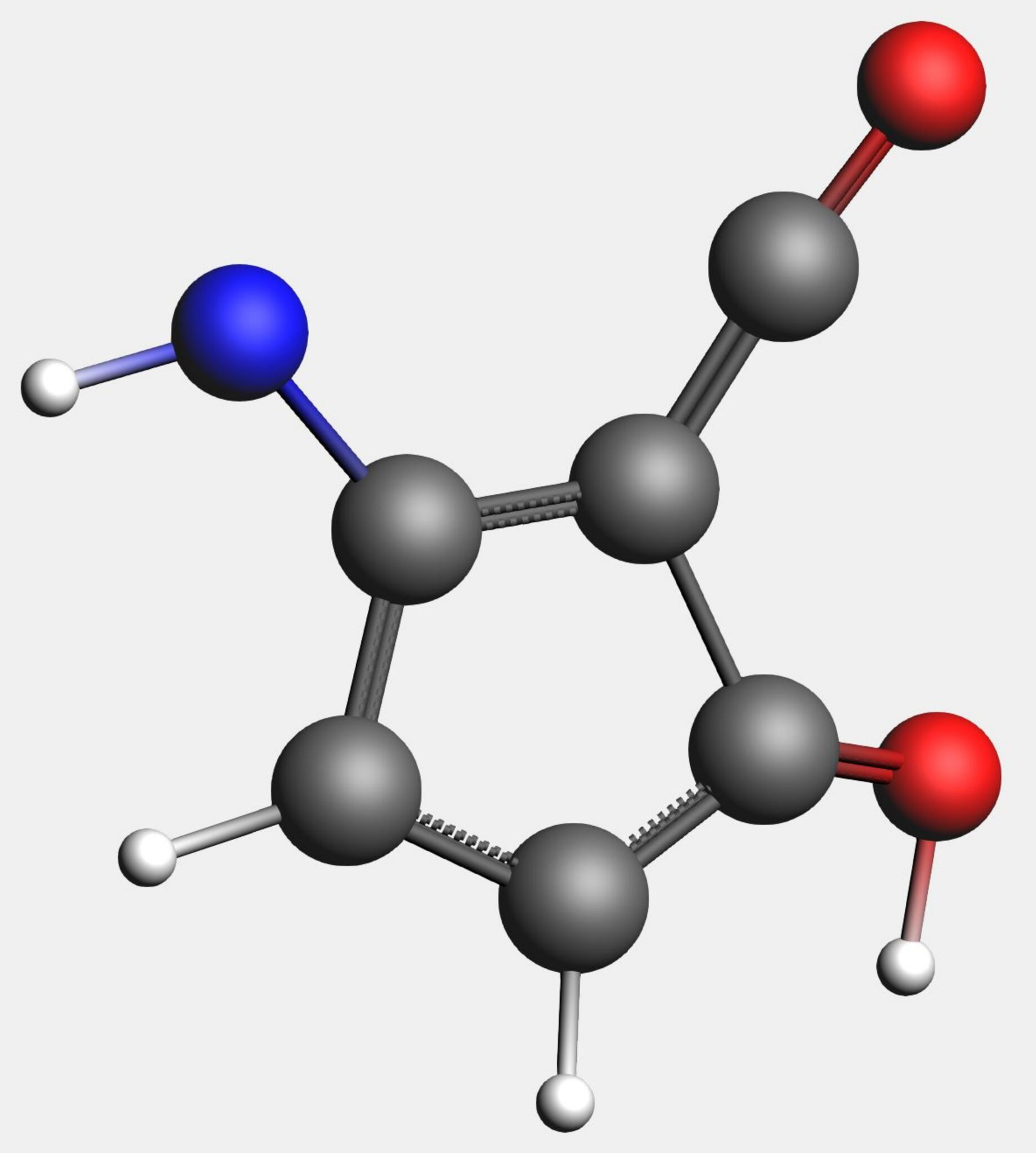

